\title{
Evaluation of four plant species for phytoremediation of copper contaminated soil
}

\begin{abstract}
Copper $(\mathrm{Cu})$ is known as the most dangerous pollutant, particularly at higher concentrations. Four forest species, namely, Jatropha curcas, Acacia mangium, Dyera costulata and Hopea odorata were used. Randomized complete block design (RCBD) with four replications was used in a factorial arrangement. The aim of this study was to assess the phytoremediation potential of the tested species for $\mathrm{Cu}$-contaminated soil. Copper sulphate $(\mathrm{CuSO} 4 \cdot 5 \mathrm{H} 2 \mathrm{O})$ was used as a source of $\mathrm{Cu}$. The different levels of $\mathrm{Cu}$ were $(\mathrm{Cu} 0=$ control, $\mathrm{Cu} 1=50, \mathrm{Cu} 2=100$, $\mathrm{Cu} 3=200, \mathrm{Cu} 4=300$ and $\mathrm{Cu} 5=400 \mathrm{mg} \mathrm{kg}-1)$. The pots were filled with growth media, and the seedlings were transplanted. The parameters monitored and analyzed were soil physiochemical properties, growth variables, plant dry biomass and heavy metal concentrations. Higher $\mathrm{Cu}$ levels significantly decreased $(\mathrm{p} \leq 0.05)$ the growth performance and the production of dry biomass. Total $\mathrm{Cu}$ concentration in tested species increased significantly ( $\mathrm{p}$ $\leq 0$. 05) with an increase in the $\mathrm{Cu}$ level. J. curcas attained the highest $\mathrm{Cu}$ removals within each level of $\mathrm{Cu}$. The BCFs of $\mathrm{Cu}$ were $>1$ within each level of $\mathrm{Cu}$ and in control media. Plant species grown in the media treated with various levels of $\mathrm{Cu}$ exhibited very small TFs $(<1)$. The highest total $\mathrm{Cu}$ concentration and the maximum $\mathrm{Cu}$ removal efficiency among plant species were observed in J. curcas. In addition, most parts of $\mathrm{Cu}$ accumulated in the roots of the four tested species. As a conclusion, J. curcas was the most effective species for phytoremediation of $\mathrm{Cu}$-contaminated soils through phytostabilization.
\end{abstract}

Keywords: Phytoremediation; Copper; Translocation factor; Bioaccumulation factor 